\title{
Present and potential factors destabilizing Central Asia as a challenge to the European Union ${ }^{1}$
}

\begin{abstract}
Central Asia is struggling with various challenges ranging from conflicts over water to ethnic and religious conflicts. Another factor destabilizing the situation is the mounting regional competition between Russia, China and the USA. While Russia is trying to maintain its zone of influence, China wants to build its own zone. US activities are mainly related to stabilization in Afghanistan. Given this background and the different problems and challenges, the EU's activities in this region are negligible. Soft instruments prevail, but EU activities are anything but coherent, as the EU lacks a broad, long-term strategy of relations with Central Asia that could redefine EU involvement in the region.
\end{abstract}

Key words: Central Asia, European Union, Fergana Valley, terrorism, conflicts

n the wake of the collapse of the Soviet Union, the independent states of Kazakhstan, Turkmenistan, Tajikistan, Uzbekistan and Kyrgyzstan emerged in Central Asia. Since their beginnings they have been coping with political, social, economic and identity crises, accompanied by a plethora of other challenges. Central Asia accounts for $1 \%$ of the global population and $1.3 \%$ of the surface of the planet, whereas its share in global GDP is more than modest at $0.3 \%$ (USD 189 billion) (Perkowska, 2013, pp. 1-13). This is not to mean that this region is in the peripheries of international politics. On the contrary, it is the focal point of competition and the clashing influences of China, Russia, the United States, and such regional actors as Iran and Turkey.

While within the USSR, the entire region was treated as a whole in terms of economic, energy, commercial and other ties. Each soviet republic located in Central Asia had a specific role to play in the soviet system of distribution and connections. The USSR promoted a uniform and complementary approach to water resources and their central management. Irrigation systems were built to enable the entire Soviet Union to take advantage of these resources. At that time, cotton fields prevailed in this region. Uzbekistan, Tajikistan, and Turkmenistan accounted for $90-95 \%$ of cotton manufactured in the USSR (Frenken, 2013, pp. 29-45). The main task of the republics of Kyrgyzstan and Tajikistan was to store up the water from the Syr Darya and Amu Darya and their tributaries to be subsequently released in summertime to irrigate the fields down the rivers. In return, Uzbekistan, Kazakhstan, and Turkmenistan, which abounded in natural resources, supplied electricity, oil and gas to the Kyrgyz and Tajik peoples. The system of aggressive irrigation aimed at increased cotton yields brought about an environmental disaster and the rapid drying of the Aral Sea. In 1960, the surface area of the Sea was

1 The paper has been written under a project financed by the National Science Centre: The European Union's attitude towards Central Asia - regional and international determinants; 2014/15/B/ HS5/01591. 
$68,500 \mathrm{~km}^{2}$ (almost equaling the surface area of the Republic of Ireland) which dropped by nearly $4 / 5$ to ca. $13,500 \mathrm{~km}^{2}$ in 2007 (Micklin, 1997).

The gravest outcome of the collapse of the USSR was the breakdown of the central water management system and of the water for electricity, oil and gas exchange. The current and potential conflicts, however, are fueled by both the emergence of new independent states (which brought about the fragmentation caused by border divisions) and by the economy. Kyrgyzstan and Tajikistan, located in the upper reaches of the Syr Darya and Amu Darya, have no other considerable resources, and thus they treat water as a commodity and argue that they bear the costs related to the maintenance of river dams. The countries located downstream, Uzbekistan, Turkmenistan and Kazakhstan consider that the rivers are also their asset and they do not intend to bear the costs of the dams. Another serious problem is posed by the erection of dams which have not been consulted with their downstream neighbors. Kyrgyzstan is building the Kambarata-1 Dam and Tajikistan - the Rogun Dam (Słojewska, 2013). The dams may curb the irrigation system. Given the persistently high birthrate and the fact that the agricultural irrigation systems affect ca. 22 million people in Central Asia, the problem of limiting their access to water resources can trigger further conflicts, including armed ones. The resources of the Syr Darya and the system of monitoring its flow across Kyrgyzstan have a specific impact on the ethnically diversified and densely populated agricultural Fergana Valley. Its surface of $124,000 \mathrm{~km}^{2}$ is divided between Kyrgyzstan, Tajikistan and Uzbekistan, and accommodates 11 million people. It is one of the most unstable regions in Central Asia, which results from the problems of escalating poverty, ethnic conflicts, obsolete infrastructure, drug trafficking and strengthening Islamic radical attitudes (Rashid, 2003, p. 193).

\section{Table 1}

\section{Fergana Valley- the main hot spots}

\begin{tabular}{|l|l||}
\hline Kyrgyzstan & Ethnic factor of destabilization \\
\hline & $\begin{array}{l}\text { The city of Osh - according to the } 1999 \text { statistics, Uzbek minority accounts for as much as } \\
49 \% \text { of the population. } \\
\text { They also account for } 1 / 3 \text { of the population in the Osh and Jalalabad districts. } \\
\text { Osh bore witness to clashes in the early 1990s and in 2010. In the latter ethnic conflict, } 250 \\
\text { persons were killed, 2,000 were injured and 400,000 were driven away as refugees. This was } \\
\text { the largest ethnic massacre since the collapse of the USSR. }\end{array}$ \\
\hline Uzbekistan & $\begin{array}{l}\text { Poverty } \\
\text { suffering poverty, over } 9 \% \text { abject poverty. }\end{array}$ \\
\hline Tajikistan & Ethnic factor of destabilization \\
\hline & The Khogent region is inhabited largely by Uzbeks. \\
\hline
\end{tabular}

Source: Own analysis based on Cierpiński, 2009 and Sikorski, 2010.

Inefficient socio-economic systems are additionally affected by demographic pressures. Over the next forty years, the population of Central Asian states is predicted to increase by ca. $30 \%$. For instance, in the most populous Uzbekistan, it is expected to grow by as much as $50 \%$ and in Tajikistan by $25 \%$. Whereas the population of Central Asia slightly exceeded 20 million in 1955, by 2016 it amounted to over 68 million. 
Differences in the demographic and territorial potential

\begin{tabular}{||l|c|l||}
\hline \multicolumn{1}{|c|}{ Country } & Population (2016) & \multicolumn{1}{c||}{ Size of territory } \\
\hline Uzbekistan & $30,300,446$ & 448.9 thousand square kilometers \\
\hline Kazakhstan & $17,855,384$ & 2.7 million square kilometers \\
\hline Tajikistan & $8,669,464$ & 143.1 thousand square kilometers \\
\hline Kyrgyzstan & $6,033,769$ & 199.9 thousand square kilometers \\
\hline Turkmenistan & $5,438,670$ & 491.5 thousand square kilometers \\
\hline
\end{tabular}

Source: Own analysis based on Central Asia Population (2016).

The peculiar nature of Central Asian political systems consists in their adherence to the authoritarian model, and even the presence of totalitarian elements in Turkmenistan. After 1991, the states in this region were forged in highly complicated political, national and religious conditions. The states of this region promoted strong leadership as a significant element of strengthening their statehoods and international positions (Bodio, Załęski, 2008, p. 260). Their political and legal systems are hybrid in nature, and despite the differences in terms of the access to natural resources and the level of civil liberties, the states of the region share a number of properties. The political and legal system was influenced by the experience of the soviet past, adapted elements of western democracies, authoritarian tendencies, local cultural factors and the specific social structure in the individual states of this region. Constitutions and legal systems have allowed the presidents of Central Asian republics to legitimize their power. In this system, the presidential center of power issues decisions on different policies, initiatives, operations and various programs. The highly personalized executive power, the absence of sufficient legal protections, corruption and relying on the political intentions of the president considerably hamper modernization and the inflow of long-term investment in many areas. Consequently, the economies are based on the sales of resources which generate relatively quick incomes for the local elite as well as international companies (Shukuralieva, 2013).

Contrary to the repressive Uzbekistan, or to the stable Kazakhstan, Kyrgyzstan witnessed several changes in the presidential office. This was not brought about in the wake of electoral procedures, but of political crises. The first Kyrgyz President, Askar Akaev, held office from 1990-2005, his successor, Kurmanbek Bakiev's term was shorter, and spanned the period from 2005-2010. The fifteen years of Akaev's presidency did not result in the deeper modernization of Kyrgyzstan, or an efficient redistribution of resources that could contribute to the development of the regions. At that time, Kyrgyzstan was benefiting from considerable international aid, and its geopolitical status improved on account of a US base being established in Manas. These undeniable opportunities and chances of development were practically squandered, due to the nepotism and corruption of President Akaev's clan and closest circle. A similar situation occurred in 2010. Social protests and an ethnic conflict brought President Bakiev down (McGlinchey, Project, 2011, pp. 80-88).

The political changes in Kyrgyzstan evidence the fact that the state elite was unable to construct efficiently operating political institutions accompanied by approved legal principles. Instead, on several occasions the relatively thin layer of the Kyrgyz political elite has 
struggled for power, not through elections but by instigating social protests and demonstrations. These tactics on the one hand evidence that a civic society is being forged, but on the other, it is risky as it sparks serious conflicts and divisions, including ethnic divisions, which already produced grave consequences in Osh and Jalalabad in 2010.

The civil war in Tajikistan from 1992-1997 was the most serious conflict since 1991. It killed ca. 100,000 people and drove ca. 1.2 million refugees away from their homes. The true reason for the long-lasting internal conflict in Tajikistan was clan struggles. The civil war resulted in religious radicalism. A part of Islamists and the democratic opposition organized within the United Tajik Opposition (UTO) consented to the conditions of agreement proposed by the authorities, while the remaining groups opted for terrorist activities instead (Lang 2013, p. 9).

Looking at the threat of Islamic terrorism, Uzbekistan illustrates this best. In 1991, extremists took advantage of the void that occurred in the local authorities and energetically set out to build their structures, including the largest organization, Adolat (Justice), operating in Namangan. Since the very beginning they proceeded to establish a network of ties in Afghanistan, the Middle East and across the whole of Central Asia. The Islamic Movement of Uzbekistan (IMU) was established in 1998 and allied with al-Qaeda. Not all Uzbek jihadists were in favor of developing a global network, though. Najmiddin Jalolov, aka Abu Yahya from the IMU was instrumental in the Islamic Jihad Union coming into existence. The dominant objective of this group is to bring Karimov's regime down (Olcott, 2012, p. 290). In spite of some internal divisions, the extensive network of the IMU is the most serious threat posed by an extremist organization to the whole of Central Asia. In 2004, Uzbekistan witnessed the biggest terrorist attacks in Tashkent and Bukhara carried out by members of Hizb ut-Tahrir, the IMU and Islamic Jihad Union (Stein, 2012, p. 78). These groups also specialized in recruiting and training new members from outside Central Asia, and they have connections with Islamic State.

Table 3

Terrorism in Central Asia

\begin{tabular}{|c|c|c|l|c|c|c||}
\hline Date & Country & City & \multicolumn{1}{|c|}{ Perpetrator Group } & $\begin{array}{c}\text { Fata- } \\
\text { lities }\end{array}$ & $\begin{array}{c}\text { Inju- } \\
\text { red }\end{array}$ & Target type \\
\hline 03.09.2010 & Tajikistan & Khujand & $\begin{array}{l}\text { Islamic Movement of Uzbekistan } \\
\text { (IMU) (suspected) }\end{array}$ & 4 & 25 & Police \\
\hline 30.07 .2004 & Uzbekistan & Tashkent & $\begin{array}{l}\text { Hizb al-Tahrir al-Islami (HT) (sus- } \\
\text { pected), Islamic Jihad Group (IJG) } \\
\text { (suspected), Islamic Movement of Uz- } \\
\text { bekistan (IMU) (suspected) }\end{array}$ & 2 & 4 & $\begin{array}{l}\text { Government } \\
\text { (General) }\end{array}$ \\
\hline 30.07 .2004 & Uzbekistan & Tashkent & $\begin{array}{l}\text { Hizb al-Tahrir al-Islami (HT) (sus- } \\
\text { pected), Islamic Jihad Group (IJG) } \\
\text { (suspected), Islamic Movement of Uz- } \\
\text { bekistan (IMU) (suspected) }\end{array}$ & 2 & 1 & $\begin{array}{l}\text { Government } \\
\text { (General) } \\
\text { (Diplomatic) }\end{array}$ \\
\hline 30.07 .2004 & Uzbekistan & Tashkent & $\begin{array}{l}\text { Hizb al-Tahrir al-Islami (HT) } \\
\text { (suspected),Islamic Jihad Group (IJG) } \\
\text { (suspected), Islamic Movement of Uz- } \\
\text { bekistan (IMU) (suspected) }\end{array}$ & 3 & 1 & $\begin{array}{l}\text { Government } \\
\text { (General) } \\
\text { (Diplomatic) }\end{array}$ \\
\hline
\end{tabular}

Source: Own analysis based on the Global Terrorism Database, https://www.start.umd.edu/gtd/search/Results.aspx?search=islamic +movement + of + uzbekistan\&sa.x=36\&sa.y=14, June 06, 2016. 
The political system in Uzbekistan is among the most repressive in Central Asia. Starting in 1990, President Islam Karimov took control of the entire state. Referenda and elections that were organized on several occasions were only a façade intended to legitimize Karimov's autocracy.

Table 4

Islam Karimov - stages of dictatorship establishment

\begin{tabular}{|c|l||}
\hline Date & \multicolumn{1}{|c|}{ Action } \\
\hline 1991 & $\begin{array}{l}\text { General nationwide vote on the change of the name of the Office of Secretary into that of Presi- } \\
\text { dent }\end{array}$ \\
\hline 1995 & Prolonging the first presidential term, scheduled to expire in 1996, to 2000 \\
\hline 2002 & Referendum on running for presidential office once more upon the expiry of the term \\
\hline
\end{tabular}

Source: Own analysis based on McGlinchey E. Project M. 2011, p. 114-115.

In the period from 2001-2005 Uzbekistan was the US's strategic ally, allowing US troops to use a base there for the ISAF operation in Afghanistan. Karimov's regime is challenged by the program of moderate Muslims founded on the idea of Islamic justice. The regime is combating moderate opposition, justifying its operations with the threat of terrorism. The authorities did not hesitate to use violence when brutally quenching the Andijan uprising on May 13-14, 2005 (Azhiben, 2008, pp. 1-11).

One of the sources of income for extremist religious groups is drug trafficking. For instance, out of 365 tons of Afghan heroin, 90 tons were transferred via Central Asia; nearly $90 \%$ of this cargo went through the Russian Federation to Europe. Central Asia is one of the transit routes used by one of the biggest global manufacturers of heroine in Afghanistan. According to the World Drug Report 2012, production of heroine in Afghanistan amounts to 5,800 tons and accounts for as much as $61 \%$ of global output (World Drug Report, 2013).

Another potentially destabilizing factor is Chinese-Russian competition, and US contributions to this competition in Central Asia. Ahmed Rashid referred to it as the Great Game (Rashid, 1997). Central Asia's essential role results from its strategic location on the borders with Russia, western China, Afghanistan, Iran and the Caspian Sea coast, and from its abundant energy resources. China's interest in its borderlands and its energy demands both attract it to this region. Kazakhstan has the richest resources and the biggest economy, while Turkmenistan offers abundant natural gas deposits. Kazakh oil can be exported to China, bypassing Russia, and the same is true for the transport of gas from Turkmenistan across Uzbekistan and Kazakhstan since 2009 (Gacek, 2013, pp. 47-62). The Shanghai Cooperation Organization embodies Chinese initiatives in the region (excluding Turkmenistan).

Following September 11, 2001, the states of this region moved closer to NATO and the US. US military bases were established in the territories of Uzbekistan and Kyrgyzstan to provide backup to the ISAF operation in Afghanistan. After the US concluded the ISAF mission and withdrew its troops from Central Asia in 2014 (and closed the base in Manas, Kyrgyzstan) US military involvement in the region was significantly curbed. Central Asia remains a significant region for Washington, however, on account of the stabilization of north Afghanistan. The countries of Central Asia have given up 
cooperation in the field of security with the Russian Federation, which was carried out within the Russia-led Collective Security Treaty Organization. Uzbekistan withdrew from the Treaty in 2012. The Russian $201^{\text {st }}$ military base is deployed in Tajikistan. Russian commercial and economic initiatives led to the Eurasian Economic Union (EEU) being established in 2015. Data reveals that the Union is primarily a political entity. Russian GDP accounts for ca. $86 \%$ of the GDP of the entire EEU; the GDP of Kazakhstan, which is second in terms of size and economic potential, amounts to nearly $10 \%$, Belarus accounts for ca. $3.5 \%$, Armenia and Kyrgyzstan - for $1 \%$ each. The individual states' trade relations with Russia (primarily Russian exports) prevail in commercial relations within the EEU. Such a bilateral system of commercial exchange between different EEU states and Russia results in a range of tensions and makes EEU members dependent on the condition of the Russian economy (Wiśniewska, 2013, pp. 37-40). Russian economic problems and the financial crisis influence the economic climate in Kazakhstan and Uzbekistan.

The 2014 conflict in Ukraine, and the Russian annexation of Crimea show that the presence of Russian minorities in specific Central Asian states can be taken advantage of by Moscow. Around 22\% of the Kazakh population are of Russian origin, only $0.9 \%$ of whom speak Kazakh. Ethnic Russians account for 7\% of the population in Kyrgyzstan, $3 \%$ in Uzbekistan, $2 \%$ in Turkmenistan and ca. $1 \%$ in Tajikistan. Russian minorities, however, are not the only tool Moscow can use to influence the situation in the region. In Kyrgyzstan, Tajikistan, and to a smaller extent in Uzbekistan, Moscow can exert financial influence on these countries, by making their respective societies highly dependent on the income generated by economic migrants to Russia (Rocznik strategiczny, 2015, p. 381). Taking into account the example of Ukraine, Kazakhstan and Kyrgyzstan are particularly wary of excessive cooperation with the EU and the US.

The states of the region are maneuvering between Russia, China and the US. Kazakhstan and Uzbekistan in particular are trying to balance out the influences exerted by external actors. Taking into account the activities, involvement and competition of China, Russia and the US, seeking influence in Central Asia, the EU remains relatively passive. In the early 1990s, the activities of the European Community in Central Asia were rather modest. Only Germany had diplomatic representatives in all five Central Asian republics, accompanied by France and Great Britain with outposts in most. If the remaining EC states were interested in the region at all, it was only via Ankara and Moscow. EU institutions followed a similar path. A Delegation of the European Commission was set up in Kazakhstan as late as 1994, and served as a middleman in the coordination of programs and initiatives. Similarly, the Partnership and Cooperation Agreements (PCA) between the EU and individual states of Central Asia were signed only several years after Ukraine and the Russian Federation had signed them. All PCA agreements pursue the same broad objectives:

- provide an appropriate framework for developing a political dialogue;

- support partner countries' efforts to consolidate their democracy, develop their economy and complete the transition into a market economy;

- promote trade and investment;

- provide a basis for legislative, economic, social, financial, civil, scientific, technological and cultural cooperation (PCA Kazakhstan, 1996). 
For instance, PCAs with Russia, Ukraine and Moldova provided for the future goal of establishing a free trade zone, whereas such plans have not been made with respect to Central Asia. The EU approached this region as less significant in comparison to other states of the former USSR, as exemplified by the resources allocated to the Technical Assistance for the Commonwealth of Independent States (TACIS). In the 1990s, the funds allocated to five Central Asian states amounted to EUR 311,800,000, compared to EUR 1,274,000,000 allocated for Russia and EUR 460,800,000 for Ukraine (Delcour, 2011, p. 94). These figures show that Central Asia was of no significance for the EU, at least not before 2001, when compared to EU involvement in other regions and states. At that time, EU initiatives boiled down to providing technical and humanitarian aid as well as allocating funds for development programs. Before 2007, no operational strategy was defined to face up to the problems and challenges posed by Central Asia.

It was only after 2001 that the situation started to transform in the wake of US involvement in Afghanistan. One of the more visible EU initiatives related to security concerns the BOMCA/CADAP programs. The Central Asia Drug Assistance Programme (CADAP) was started in 1996; the Border Management Programme in Central Asia (BOMCA) followed in 2001 and sealed the borders against smuggling and drug trafficking (Matveeva, 2006, p. 96). The EU-Uzbekistan relations suffered a crisis in 2005. After Karimov's regime bloodily suppressed the uprising in Andijan, the EU imposed sanctions on Uzbekistan. The EU decided to suspend the Cooperation Committee and subcommittees' meetings under the PCA (Hartman, 2016, p. 65). The political situation in Kyrgyzstan was equally complicated in 2005 and again in 2010. In the latter case, the response from the EU brought about positive outcomes and aided the efforts to conclude the political-ethnic conflict there (Kozłowski, 2012, p. 84). Despite the difficulties and negligible progress of democratization, in June 2007, the European Council announced the Strategy for a New Partnership with this region for the period after 2007. The Strategy defined the priorities of EU involvement in Central Asia (The European Union and Central Asia: The New Partnership in action, 2009):

- enhancing respect for the rule of law;

- human rights and good governance;

- developing transparent democratic political structures;

- promoting economic development, trade and investment;

- strengthening energy and transport links;

- improving environmental and water sustainability;

- combating common threats and challenges (for example, trafficking, illegal migration).

The growing EU involvement in Central Asia resulted in EU representatives being sent to Kazakhstan, Kyrgyzstan, Tajikistan and Uzbekistan, alongside the EU Special Representative for Central Asia. Despite the escalation of EU diplomatic activities in the region, no satisfactory results have been attained in nearly a decade. One obstacle is the authoritarian system exercised in the "presidential" republics. Regional partners are interested in neither political liberalization, nor the rule of law, nor in building the institutions of a civic society. The relations between Central Asian states and the EU are also impaired by the Moscow-Brussels crisis. Finally, the EU is placing considerable attention on the situation in the Middle East and the migration crisis, not to mention the 
challenges the euro zone is facing. The accumulation of these threats and challenges emerging in the immediate neighborhood, and inside the EU has considerably curbed EU activities in Central Asia which will result in further marginalization of the EU in this region in favor of the dynamically developing activities of China.

\section{Conclusions}

States in Central Asia are struggling with a number of problems, including strong authoritarian tendencies; economic backwardness; excessive dependence on income from oil and gas exports; ethnic, clan and religious conflicts; problems with water; drug smuggling and Islamic extremism. The Russian Federation is trying to retain its zone of political, military and economic influence. Russia is facing a potential competitor in China, which is interested in this region on account of its plans for a new silk road and its energy demands. Succession of power can generate problems and lead to a tug-of-war between different interest groups.

Taking into account the above problems and challenges, the EU has failed to mark its presence since 2014. In the period from 2007-2013 the EU's new strategy for partnership seemed to make it a more influential actor in terms of soft policy, gradually promoting the development of civic society institutions and as a mediator, seeking to resolve different political conflicts, such as that in Kyrgyzstan in 2010.

When assessing the EU's involvement in this region so far, it has to be deemed unsatisfactory. This is partly related to the aversion of authoritarian regimes to the liberalization of power. The EU does not have an influence on security comparable to that Russia, China and the US have. Soft instruments typically bear fruit in the long term, whereas Russia has maintained its potential to influence the security and policies of individual states in the region, and the Ukrainian crisis has evidenced that the issue of Russian minorities can become a tool in Moscow's hands.

The EU is facing the task of redefining its involvement in Central Asia. Taking into account the experience gathered after 1991, EU initiatives are unlikely to succeed if the EU continues to be selective when approaching different challenges in the region. The hindrances to the EU's greater involvement in Central Asia are not so much related to the region itself, but rather result from internal EU problems, such as the crisis in Greece, Brexit and the migration crisis. The accumulation of these factors is likely to result in limited EU involvement in Central Asia, and new initiatives and activities are unlikely in the immediate future.

\section{Bibliography}

Azhiben S. (2008), The Andijan Events: Radical Islam and Conflict in Uzbekistan, "Conflict \& Communication Online,” vol. 7, no. 1, http://www.cco.regener-online.de/2008_1/pdf/azhiben.pdf, May 20, 2016.

Bodio T., Załęski P. (2008), Problemy budowy społeczeństwa obywatelskiego w państwach Azji Centralnej, in: Region Azji Centralnej jako obszar wplywów międzynarodowych, eds. B. Bojarczyk, A. Ziętek, Lublin. 
Central Asia Population (2016), http://www.worldometers.info/world-population/central-asia-population/, May 17, 2016.

Cierpiński Z. (2009), Kotlina Fergańska rozsadnik ,,narkoislamizmu”, http://www.psz.pl/116-bezpieczenstwo/kotlina-ferganska-rozsadnik-narkoislamizmu, May 13, 2016.

Delcour L. (2011), Shaping the Post-Soviet Space? EU Policies and Approaches to Region-Building, Burlington.

The European Union and Central Asia: The New Partnership in action (2009), http://eeas.europa.eu/ central_asia/docs/2010_strategy_eu_centralasia_en.pdf, June 10, 2016.

Frenken K. (2013), Food and Agriculture Organization of the United, Irrigation In Central Asia In Figures, "AQUASTAT Survey" - 2012, Rome.

Hartman J. W. (2016), The May 2005 Andijan Uprising: What We Know, Central Asia-Caucasus Institute \& Silk Road Studies Program-A Joint Transatlantic Research and Policy Center, "Silk Road Paper".

Gacek Ł. (2013), Azja Centralna w polityce energetycznej Chin, Wydawnictwo Uniwersytetu Jagiellońskiego, Kraków.

Kozłowski K. (2012), Kolory Rewolucji, Poltext, Warszawa.

Lang J. (2013), The radical Islamic militants of Central Asia, New York.

Matveeva A. (2006), EU Stakes in Central Asia, "Chaillot Papers" no. 91, July, special issue.

McGlinchey E. Project M. (2011), Chaos, Violence, Dynasty: Politics And Islam In Central Asia, University of Pittsburgh Press, Pittsburgh.

Micklin P. (2007), The Aral Sea Disaster, “Annual Review of Earth and Planetary Sciences” vol. 35, http://www.terras-altas.net.br/MA-2013/desastres\%20ambientais/AralSeaDisaster.pdf, May $18,2016$.

Olcott M. B. (2012), In The Whirlwind Of Jihad, Brookings Institution Press, Washington, DC.

PCA-Kazakstan (1996), http://ec.europa.eu/external_relations/central_asia/pca/index_en.htm, June 10, 2016.

Perkowska A. (2013), Dezintegracja regionu Azji Centralnej jako pochodna uwarunkowań wewnętrznych, "Polityka i Bezpieczeństwo", no. 2.

Rashid A. (1997), The New Great Game - the Battle for Central Asia's Oil, "Far Eastern Economic Review", 10 April.

Rashid A. (2003), Dżihad. Narodziny wojujacego islamu w Azji Środkowej, Warszawa.

"Rocznik strategiczny" 2014/15 (2015), Przeglad sytuacji politycznej, gospodarczej i wojskowej w środowisku międzynarodowym Polski, vol. 20, Warszawa.

Shukuralieva N. (2013), Globalny rozwój w kontekście społeczno-gospodarczych wyzwań Azji Środkowej i Kaukazu Południowego, projekt współfinansowany przez Ministerstwo Spraw Zagranicznych RP w ramach programu Polska Pomoc.

Sikorski T. (2010), Masakry etniczne w Kirgistanie przyczyny oraz reakcje międzynarodowe, "Biuletyn” Polskiego Instytutu Stosunków Międzynarodowych, no. 98, Warszawa, http://www.pism. pl/zalaczniki/Biuletyn_706.pdf, May 15, 2016.

Słojewska A., Wielkie bitwy o wodę, http://www.rp.pl/artykul/1035598-Wielkie-bitwy-o-wode. html\#ap-2, May 17, 2016.

Stein M. (2012), Uzbekistan's View of Security in Afghanistan After 2014, "Military Review”, vol. 92, issue 3.

Wiśniewska I. (2013), Integracja euroazjatycka rosyjska próba ekonomicznego scalenia obszaru poradzieckiego, "Prace OSW", no. 44, Warszawa.

World Drug Report (2013), United Nations on Drugs and Crime, Vienna. 


\section{Obecne i potencjalne czynniki destabilizacji Azji Środkowej jako wyzwanie dla Unii Europejskiej ${ }^{2}$}

\section{Streszczenie}

Azja Centralna boryka się z różnymi wyzwaniami od konfliktów o wodę, po na tle etnicznym, religijnym. Kolejnym czynnikiem destabilizacyjnym jest rosnąca rywalizacja w regionie pomiędzy Rosją, Chinami i USA. O ile Rosja chce utrzymać swoją strefę wpływów, o tyle Chiny chcą zbudować swoją. Aktywność USA związana jest przede wszystkim ze stabilizacją Afganistanu. Na tym tle oraz wobec różnych problemów i wyzwań, aktywność UE jest niewielka. Przeważają instrumenty miękkie, ale działania UE nie są spójne, bowiem brakuje szerszej i długofalowej strategii wobec Azji Centralnej, która przedefiniowałaby zaangażowanie unijne wobec tego regionu.

Słowa kluczowe: Azja Środkowa, Unia Europejska, Kotlina Fergańska, terroryzm, konflikty

${ }^{2}$ Artykuł przygotowany ramach projektu finansowanego przez Narodowe Centrum Nauki: „Unia Europejska wobec Azji Środkowej - uwarunkowania regionalne i międzynarodowe” 2014/15/B/ HS5/01591. 